\title{
Remission of a Pregnant Woman with Persistent Hyperemesis Gravidarum with Corticosteroid Treatment
}

\section{Dirençli Hiperemezis Gravidarumun Kortikosteroid ile Remisyonu}

\author{
(D) Tuğba Özcan Aydın, (D Özlem Yüksel Aybek, (D Sevde Nur Su, (D) Tuba Alptekin Karapolat, \\ (D) Şeyma Yesiralioğlu
}

University of Health Sciences Turkey, İstanbul Bağcılar Training and Research Hospital, Clinic of Obstetrics and Gynecology, İstanbul, Turkey

\section{Abstract}

\begin{abstract}
Nausea and vomiting affect more than $50 \%$ of pregnancies. It presents a broad spectrum of symptoms ranging from mild symptoms to severe weight loss and that may affect daily activities. Hyperemesis gravidarum is a severe pathologic form of nausea and vomiting of pregnancy characterized by a greater than $5 \%$ loss of weight and unexplained ketonuria. Hyperemesis gravidarum affects approximately $0.5 \%$ of pregnancies. The pathogenesis of hyperemesis gravidarum is not exactly known but multifactorial. Previous pregnancy history, low body mass index, maternal inheritance, maternal mood disorders are thought to be associated with. Other causes of nausea and vomiting, such as gastrointestinal tract, genitourinary system, central nervous system, toxic metabolism, must be ruled out. The risk factors include family history, obstetric history, molar pregnancy, multiple pregnancy, nulliparity, female fetus, hyperthyroidism, diabetes, asthma, depression, peptic ulcer or other gastrointestinal disorders. Severe symptoms affect daily activities, cause anxiety, and sometimes may even lead to the termination of pregnancy and cancellation of future pregnancy plans. The symptoms that started in the first trimester of pregnancy decrease and recover to starting of the second trimester. In our case, we will discuss the successful treatment of severe form of hyperemesis gravidarum with parenteral and oral corticosteroids atypically in the second trimester.
\end{abstract}

Keywords: Corticosteroids, hyperemesis gravidarum, Helicobacter pylori

\section{Öz}

\begin{abstract}
Bulantı ve kusma, gebeliklerin \%50'sinden fazlasını etkiler. Gebelik bulantı ve kusmaları hafif semptomlardan şiddetli kilo kaybına kadar değişen ve günlük aktiviteleri etkileyebilecek geniş bir semptom yelpazesi sunar.

Hiperemezis gravidarum, gebelikte bulantı ve kusmanın şiddetli patolojik bir formudur ve $\% 5^{\prime}$ ten fazla kilo kaybı ve açıklanamayan ketonüri ile karakterizedir. Hiperemezis gravidarum, gebeliklerin yaklaşık \%0,5'ini etkiler. Hiperemezis gravidarumun patogenezi tam olarak bilinmemekle birlikte multifaktöriyeldir. Önceki gebelik öyküsü, düşük vücut kitle indeksi, annenin genetik öyküsü, anneden gelen duygudurum bozuklukları ile ilişkili olduğu düşünülmektedir. Gastrointestinal sistem, genitoüriner sistem, merkezi sinir sistemi gibi diğer bulantı ve kusma nedenleri ekarte edilmelidir. Risk faktörleri arasında aile öyküsü, obstetrik öykü, molar gebelik, çoğul gebelik, nulliparite, dişi fetüs, hipertiroidizm, diyabet, astım, depresyon, peptik ülser veya diğer gastrointestinal bozukluklar yer alır. Şiddetli semptomlar günlük aktiviteleri etkiler, kaygıya neden olur ve hatta bazen gebeliğin sonlandırılmasına ve gelecekteki gebelik planlarının iptal edilmesine neden olabilir. Gebeliğin ilk trimesterında başlayan semptomlar azalır ve ikinci trimesterın başlangıcına kadar düzelir. Olgumuzda atipik olarak ikinci trimesterde görülen şiddetli hiperemezis gravidarumun parenteral ve oral kortikosteroidlerle başarılı tedavisini tartışacağız.
\end{abstract}

Anahtar kelimeler: Hiperemezis gravidarum, Helikobakter pilori, kortikosteroid

Address for Correspondence: Tuğba Özcan Aydın, University of Health Sciences Turkey, İstanbul Bağcılar Training and Research Hospital, Clinic of Obstetrics and Gynecology, İstanbul, Turkey

E-mail: drtugba.ozcan@gmail.com ORCID ID: orcid.org/0000-0002-1804-5712 Received: 04.02.2021 Accepted: 15.06.2021

Cite this article as: Özcan Aydın T, Aybek ÖY, Su SN, Alptekin Karapolat T, Yesiralioğlu Ş. Remission of a Pregnant Woman with Persistent Hyperemesis Gravidarum with Corticosteroid Treatment. Bagcilar Med Bull 2021;6(3):346-349

${ }^{\circ}$ Copyright 2021 by the Health Sciences University Turkey, Bagcilar Training and Research Hospital Bagcilar Medical Bulletin published by Galenos Publishing House. 


\section{Introduction}

Nausea and vomiting affect more than $50 \%$ of pregnancies. It presents a broad spectrum of symptoms ranging from mild symptoms to severe weight loss, which may affect daily activities. Hyperemesis gravidarum is a severe pathologic form of nausea and vomiting of pregnancy, characterized by a greater than $5 \%$ loss of weight and unexplained ketonuria (1). Hyperemesis gravidarum affects approximately $0.5 \%$ of pregnancies (2). The pathogenesis of hyperemesis gravidarum is not exactly known but multifactorial. Previous pregnancy history, low body mass index, maternal inheritance, and maternal mood disorders are thought to be associated with it (3). Other causes of nausea and vomiting, such as gastrointestinal tract, genitourinary system, central nervous system, and toxic metabolism, must be ruled out (4). The risk factors include family history, obstetric history, molar pregnancy, multiple pregnancy, nulliparity, female fetus, hyperthyroidism, diabetes, asthma, depression, peptic ulcer or other gastrointestinal disorders (5). Severe symptoms affect daily activities, cause anxiety, and sometimes may even lead to the termination of pregnancy and cancellation of future pregnancy plans $(6,7)$. The symptoms starting in the first trimester of pregnancy decrease and recover until the start of the second trimester. In our case, we will discuss the successful treatment of severe form of hyperemesis gravidarum with parenteral and oral corticosteroids atypical in the second trimester.

\section{Case Report}

A 21-year-old primigravid who had 18 weeks and 2 days pregnancy from her last period was admitted to the obstetrics and gynecology outpatient clinic with nausea and vomiting. In the detailed history, it was learned that the patient had no other known disease except gastritis, and had undergone endoscopy before pregnancy and had received antibiotherapy for Helicobacter pylori infection. She stated that the nausea and vomiting symptoms had started at the $6^{\text {th }}$ week of pregnancy, showed continuity during the day, and awakened her from the night sleep. She had not benefited from the initial treatment and she had received medical treatment with hospitalization twice. Biopsies taken from the stomach antrum in the evaluation of endoscopy performed in the first trimester of pregnancy were reported as chronic antral gastritis but not Helicobacter pylori infection. The patient had been $45 \mathrm{~kg}$ at the beginning of pregnancy but she was $39 \mathrm{~kg}$ at our first examination. In the examination of the patient, the mucous membranes were dehydrated and pale, blood pressure was $100 / 70 \mathrm{mmHg}$, heart rate was $80 / \mathrm{min}$, and body temperature was $36.4{ }^{\circ} \mathrm{C}$. There was no abdominal sensitivity or contraction of uterus. She did not describe vaginal bleeding or premature rupture of membranes. In the ultrasonography evaluation, single, live fetus with measurements compatible with gestational week was observed. The placenta was grade 1 degree, natural, and located in the anterior of the uterus. The laboratory examinations of the patient were as follows: Hemoglobin: $11 \mathrm{~g} / \mathrm{dL}$, hematocrit: $30.8 \%$, white blood cells: $8.98 \mathrm{~m} / \mathrm{uL}$, aspartate transaminase: $22 \mathrm{u} / \mathrm{L}$, alanine transaminase: 13 $\mathrm{u} / \mathrm{L}$ thyroid-stimulating hormone: $0.66 \mathrm{miu} / \mathrm{L}$, free t3: 3.41 $\mathrm{nmol} / \mathrm{L}$, free t4: $0.94 \mathrm{nmol} / \mathrm{L}$, and ketones 2+ in urinalysis. She stated that she had metoclopramide (metpamid $₫ 10 \mathrm{mg}$ once a day peroral), ginger extract (emetium ${ }^{\circledR} 200 \mathrm{mg}$ twice a day peroral), trimetobenzamide hydrochloride (emedur ${ }^{\circledR}$ twice a day peroral) treatments and the last step treatment as ondansetron (zofran ${ }^{\circledR} 8 \mathrm{mg} 3$ times a day peroral) but she did not benefit any of them and hospitalized to our obstetrics and gynecology clinic. The oral intake of the patient was restricted and parenteral treatment was started. 3.000 cc balanced fluid per day, (1.000 cc lactated ringer, 1.000 cc $0.9 \%$ isotonic sodium chloride, 1.000 cc $10 \%$ dextrose) which included dekspanthenol (beheptal 3 times a day), ascorbic acid (acmel ${ }^{\circledR} 3$ times a day), metoclopramide (metpamid ${ }^{\circledR} 3$ times a day), ranitidine (ragasit ${ }^{\circledR} 3$ times a day) was applied as an initial treatment. When the patient did not benefit from these treatments, ondansetron (zofran ${ }^{\circledR} 8 \mathrm{mg}$ intravenous once a day) and sodium alginate (gaviscon ${ }^{\circledR} 3$ times a day peroral) were added to the current treatment. On the seventh day of ondansetron treatment, the patient's complaints continued and weight gain was not observed so we started glucocorticoid treatment. $16 \mathrm{mg}$ methylprednisolone (prednol ${ }^{\circledR} 3$ times a day intravenously) was given intravenously on the first two days of treatment and continued peroral. Oral treatment was started with 32 mg methylprednisolone and reduced to half-dose every two days and adjusted to $4 \mathrm{mg}$ at the end of the first week. A dramatic regression of nausea and vomiting symptoms, weight gain and improvement in laboratory parameters were observed since corticosteroid treatment was initiated, so the patient was discharged with $4 \mathrm{mg}$ oral steroid treatment in the second week of the hospitalization. The patient was $47 \mathrm{~kg}$ at discharge and she tolerated oral intake. $4 \mathrm{mg}$ of oral steroid treatment was continued for one week and steroid treatment was terminated due to the obvious clinical and laboratory improvement.

Finally, she came with labor contractions and had 6 $\mathrm{cm}$ cervical dilation and $70 \%$ effacement in her vaginal examination, and was admitted for vaginal delivery in 37 weeks and 4 days of pregnancy. A female 2.980 gr baby, who had 9 APGAR scores at the first minute of birth and 10 
APGAR scores at the fifth minute of birth, was born. The baby was examined at the age of one and her development was normal.

\section{Discussion}

Nausea and vomiting in pregnancy or severe form, which is hyperemesis gravidarum, is a clinical description without definitive diagnostic criteria. Epidemiology is unknown but multifactorial. Patients who are younger and have first pregnancy are more affected than older and multiparous patients, but there are no exact data (8). Risk factors include a history of hyperemesis in previous pregnancy, gastrointestinal diseases, history of migraine, molar pregnancy, and female fetus. Genetic factors also play a major role. The patients whose mother and sister are affected have excess risk (9). Considering the risk factors, our patient's history of Helicobacter pylori infection and gastritis warns us to see the severe form of nausea and vomiting of pregnancy.

The symptoms of hyperemesis gravidarum start at gestational weeks of 5-6, peak at $9^{\text {th }}$ week, and decrease at weeks of $16-20.15-20 \%$ of the patients can remain symptomatic until third trimester and rarely $5 \%$ until the birth (10-12). The symptoms of our patient started typically at week 6 , and intensified and persisted until the $18^{\text {th }}$ week of gestation. The pathogenesis of the disease is not known exactly but hormonal changes and gastrointestinal diseases are responsible. Many women with Helicobacter pylori infection do not develop severe nausea, but there are studies which take place in literature, showing that this infection is associated with hyperemesis. In the meta-analysis of 26 epidemiological studies published in 2014, it was found that Helicobacter pylori infection was significantly associated with nausea and vomiting and hyperemesis gravidarum compared to the asymptomatic control group (13). Our patient's medical history revealed endoscopic biopsy due to dyspeptic symptoms and Helicobacter pylori infection was detected. Although eradication has been achieved with antibiotherapy, recurrent complaints of the patient support the role of gastrointestinal system diseases in the underlying pathogenesis of resistant hyperemesis gravidarum. Nausea of pregnancy and hyperemesis gravidarum treatment is shaped according to the clinical status of the patient. Initial treatment approach includes diet and lifestyle change in patients with no symptoms of hypovolemia, ketonuria, electrolyte imbalance only with symptoms of nausea; and patients should avoid situations that trigger nausea. In patients with mild symptoms, ginger and/or pyridoxine can be used, and if symptoms persist, an antihistaminic group may be added to the treatment. Metoclopramide, promethazine, and prochlorperazine are other treatment options. Ondansetron can be given either orally or parenterally to resistant cases. Many patients benefit from treatment at this stage. Although a drug is used for a week and clinical symptoms do not improve, another drug group should be added (14). A randomized controlled trial of ondansetron showed a significant reduction in symptoms of nausea and vomiting compared to the combination of doxylamine and pyridoxine (15). In another randomized study, ondansetron has been shown to be effective in vomiting compared to metoclopramide but not to reduce the symptoms of nausea (16). In the studies performed, there was no evidence that ondansetron increased congenital malformations in early pregnancy, but in a few studies, ondansetron was associated with cardiovascular malformation and cleft palate (17).According to the stepwise treatment approach, we performed primarily lifestyle change and oral treatment to our patient. Ondansetron was given as the last step of oral treatment; however, with the increase in the severity of the symptoms including weight loss, laboratory parameters deterioration and difficult total oral intake, she was hospitalized for parenteral treatment. At this stage of treatment, oral intake of the patient who does not benefit from oral pharmacotherapy should be restricted, electrolyte imbalance and ketonuria should be followed. In addition to intravenous hydration and pharmacotherapy, thiamine (vitamin B1) should be given to prevent Wernicke's encephalopathy. We restricted oral intake of the patient and used intravenous hydration, vitamin B complex, intravenous metoclopramide and ondansetron treatments during the hospitalization. In spite of all these treatments, there was no regression in the symptoms and no improvement in laboratory findings and the patient was started on corticosteroids.

Although the mechanism of action is not understood, it is known that corticosteroid is used as an effective antiemetic agent in oncology patients. Several previous studies have reported successful responses in pregnant women, too. However, the studies on this subject are not strong. In a placebo-controlled randomized study of 126 women, there are no side effects on pregnant women and neonates using oral and parenteral corticosteroid therapy in hyperemesis gravidarum. In severe hyperemesis and placebo group study of 110 women, the hospitalization rate of women who used glucocorticoid was similar to the placebo group (17). According to a systematic review of 3 randomized clinical trials by McParlin et al. (18), patients who used glucocorticoid with placebo, glucocorticoid with promethazine or glucocorticoid with metoclopramide were compared and patients were reported to benefit from glucocorticoid. Symptoms were regressed with glucocorticoid in resistant hyperemesis gravidarum (18). It 
has been shown to be associated with a slight increase in the risk of cleft palate before the $10^{\text {th }}$ gestational week on glucocorticoid use. Therefore, the use of glucocorticoids in the first trimester should be avoided $(19,20)$. After intravenous administration of glucocorticoids, oral form should be given and the treatment should be decreased and stopped.

\section{Conclusion}

Nausea of pregnancy and hyperemesis gravidarum are one of the most important diseases that can affect the pregnant women, limit their daily activities, and cause emotional and psychologic problems. In untreated cases, it may lead to general condition disorder due to deterioration in laboratory parameters such as electrolyte imbalance, even maternal and fetal death. There are various oral and parenteral pharmacological agents that are used in the treatment of hyperemesis gravidarum. Rarely, patients do not benefit from standard treatment. Short-term corticosteroid therapy can be used in resistant cases of hyperemesis gravidarum. Antenatal use of corticosteroids has been reported as safe after palate formation in pregnancies older than 10 weeks. Patients with severe hyperemesis gravidarum have a dramatic improvement in clinical and laboratory parameters with oral corticosteroid treatment following parenteral treatment.

\section{Ethic}

Informed Consent: Only consent of patient has taken because of case report.

Peer-review: Externally and internally peer-reviewed.

\section{Authorship Contributions}

Concept: T.Ö.A., Ö.Y.A., S.N.S., T.A.K., Ş.Y., Design: T.Ö.A., Ö.Y.A., S.N.S., T.A.K., Ş.Y., Critical Review of the Article: T.Ö.A., Ö.Y.A., S.N.S., T.A.K., Ş.Y., Writing: T.Ö.A., Ö.Y.A., S.N.S., T.A.K., Ş.Y.

Conflict of Interest: No conflict of interest was declared by the authors.

Financial Disclosure: The authors declared that this study received no financial support.

\section{References}

1. Cappell MS. Obstetrics: normal and problem pregnancies, Chapter 48. Philadelphia: Elseiver; 2017:1012-1029.

2. Koch KL, Frissora CL. Nausea and vomiting during pregnancy. Gastroenterol Clin North Am 2003;32(1):201-234, vi.

3. McCarthy FP, Lutomski JE, Greene RA. Hyperemesis gravidarum: current perspectives. Int J Womens Health 2014;6:719-725.
4. Campbell K, Rowe H, Azzam H, Lane CA. The Management of Nausea and Vomiting of Pregnancy. JGOC 2016;9(1):98-112.

5. Gabra A. Risk Factors of Hyperemesis Gravidarum: Review Article. Health Sci J 2018;12(6):603.

6. Tan A, Lowe S, Henry A. Nausea and vomiting of pregnancy: Effects on quality of life and day-to-day function. Aust N Z J Obstet Gynaecol 2018;58(3):278-290.

7. Heitmann K, Nordeng H, Havnen GC, Solheimsnes A, Holst L. The burden of nausea and vomiting during pregnancy: severe impacts on quality of life, daily life functioning and willingness to become pregnant again - results from a cross-sectional study. BMC Pregnancy Childbirth 2017;17(1):75.

8. Klebanoff MA, Koslowe PA, Kaslow R, Rhoads GG. Epidemiology of vomiting in early pregnancy. Obstet Gynecol 1985;66(5):612-616.

9. Zhang Y, Cantor RM, MacGibbon K, Romero R, Goodwin TM, Mullin PM, et al. Familial aggregation of hyperemesis gravidarum. Am J Obstet Gynecol 2011;204(3):230.e1-e7. doi: 10.1016/j. ajog.2010.09.018.

10. Gadsby R, Barnie-Adshead AM, Jagger C. A prospective study of nausea and vomiting during pregnancy. Br J Gen Pract 1993;43(371):245-248. Erratum in: Br J Gen Pract 1993;43(373):325.

11. Goodwin TM. Hyperemesis gravidarum. Obstet Gynecol Clin North Am 2008;35(3):401-417.

12. Fell DB, Dodds L, Joseph KS, Allen VM, Butler B. Risk factors for hyperemesis gravidarum requiring hospital admission during pregnancy. Obstet Gynecol 2006;107(2 Pt 1):277-284.

13. Niemeijer MN, Grooten IJ, Vos N, Bais JM, van der Post JA, Mol BW, et al. Diagnostic markers for hyperemesis gravidarum: a systematic review and metaanalysis. Am J Obstet Gynecol 2014;211(2):150.e1e15. doi: 10.1016/j.ajog.2014.02.012

14. Smith AJ, Fox KA, Clark SM, Treatment and outcome of nausea and vomiting of pregnancy, Up to Date, aug, 2021, https//https://www. uptodate.com/contents/nausea-and-vomiting-of-pregnancytreatment-and-outcome.

15. Oliveira LG, Capp SM, You WB, Riffenburgh RH, Carstairs SD. Ondansetron compared with doxylamine and pyridoxine for treatment of nausea in pregnancy: a randomized controlled trial. Obstet Gynecol 2014;124(4):735-742.

16. Kashifard M, Basirat Z, Kashifard M, Golsorkhtabar-Amiri M, Moghaddamnia A. Ondansetrone or metoclopromide? Which is more effective in severe nausea and vomiting of pregnancy? A randomized trial double-blind study. Clin Exp Obstet Gynecol 2013;40(1):127-130.

17. Yost NP, McIntire DD, Wians FH Jr, Ramin SM, Balko JA, Leveno KJ. A randomized, placebo-controlled trial of corticosteroids for hyperemesis due to pregnancy. Obstet Gynecol 2003;102(6):12501254.

18. McParlin C, O’Donnell A, Robson SC, Beyer F, Moloney E, Bryant A, et al. Treatments for hyperemesis gravidarum and nausea and vomiting in pregnancy: a systematic review. JAMA 2016;316(13):1392-1401.

19. Shepard TH, Brent RL, Friedman JM, Jones KL, Miller RK, Moore CA, et al. Update on new developments in the study of human teratogens. Teratology 2002;65(4):153-161.

20. Carmichael SL, Shaw GM. Maternal corticosteroid use and risk of selected congenital anomalies. Am J Med Genet 1999;86(3):242244. 